\title{
Concessions within the maritime-terrestrial public domain on the beaches of southeastern Spain
}

\author{
A. Palazón ${ }^{\mathrm{a}}$, I. López ${ }^{\mathrm{b}, *}$, V. Gilart ${ }^{\mathrm{c}}$, L. Bañón ${ }^{\mathrm{b}}$, L. Aragonés ${ }^{\mathrm{b}}$ \\ ${ }^{a}$ Dept. of Civil Engineering, Catholic University of Murcia, Campus de los Jerónimos, $N^{o} 135$ Guadalupe, 30107, Murcia, Spain \\ ${ }^{\mathrm{b}}$ Dept. of Civil Engineering, University of Alicante, Carretera San Vicent del Raspeig $s / n, 03690$, Alicante, Spain \\ ${ }^{c}$ Dep. of Computing Technology and Computing, University of Alicante, Carretera San Vicent del Raspeig s/n, 03690, Alicante, Spain
}

\section{A R T I C L E I N F O}

\section{Keywords:}

Beach

Concession

Tourism

Hammock rentals

Shoreline

\begin{abstract}
A B S T R A C T
Tourism makes an important contribution to the economies of some territories, especially 'sun and sand' tourism that uses public domain areas. Some of these areas are operated through concession systems. This article studies the evolution of 31 eminently touristic beaches in 5 provinces of the Spanish Mediterranean coast during the period 2005-2016, analysing both their physical (shoreline evolution) and administrative (concessions documents) aspects. For this purpose, orthophotos interpreted by Geographic Information Systems are used, as well as the concession contract for each beach. The results obtained show that first, there is no relationship between the evolution of the shoreline and the surface area that is assigned under the concession agreement. Second, concessions do not follow uniform criteria (i.e., set boundaries, surface area, annual fee or distance from the water line). Despite the existence of specific legislation applicable to the entire Spanish coastline, there also exist loopholes in it. The conclusion of the study is that for the sustainable management of these areas, it is necessary to link the physical aspects of beaches with the management of the public domain. This would achieve a balance between the natural, economic and social aspects of the territory, and would ensure that there is no decrease in the quality of the beach, which would have a negative impact on visitor satisfaction. This is crucial to avoid in the tourism sector, which is a key GDP contributor for many countries.
\end{abstract}

\section{Introduction}

Coastal areas are one of the most popular tourist destinations in the world (Holden, 2000; Sánchez, 2001), particularly Spain's Mediterranean coastline. This is due to its ideal climatic conditions, in addition to the large extension of beaches, that constitute one of the most important attractions of world mass tourism within the "sun and sand tourism model" (Sardá et al., 2014).

Numerous studies show that the coast offers citizens a strategic place for commercial activity and transport, in addition to having a wide range of services and recreational and social alternatives (EEA, 2006). Likewise, the high tourist indicators indexes in coastal towns and cities have promoted socio-economic aspects, especially in coastal infrastructures (Keul, 2015). This kind of infrastructure (hotels, restaurants, etc.), allows the needs of the users, mainly tourists, to be satisfied (Aguiló et al., 2003). Europe is the world's leading tourist destina-

\footnotetext{
* Corresponding author.

Email address: isalopu.il@gmail.com (I. López)
}

tion, receiving half of the total number of international tourists, with an annual growth of $8 \%$ in 2017 (UNWTO, 2018). Tourism contribution to GDP of some countries is very significant, to the extent that it is considered one of the main industries, and, therefore, good management is necessary. In the case of management of natural public assets, the manager must make the best decisions for society by maintaining the functionality of natural systems and avoiding the degradation of goods and services (Sardá et al., 2014). As the demand for the use of public spaces is growing, management becomes more complicated (Dormios et al., 2000), therefore different management systems have been developed based on different criteria: (i) quality (ISO Standards), and (ii) Environmental Management Systems on beaches (EMSBs). These systems facilitate working under the principles of Integrated Coastal Zone Management (Sardá et al., 2012) to obtain a sustainable coastal system that will accommodate the increase in anthropogenic pressure (Barragán, 2005; Sardá et al., 2005).

However, applying ecosystem management principles in practice is still seen by many social agents as confusing due to unclear terminol- 
ogy, which, combined with complex system of institutions with highly fragmented legal remit, gets it even more complicated (Bainbridge et al., 2011; Cormier et al., 2010). In the Spanish case, the administrative and maintenance scheme for beach management is equally complicated due to the overlapping and uncoordinated jurisdictions between national and local administrations (Ariza et al., 2008; Breton et al., 1996). To try to regulate this area, the Coastal Law of 1969 was developed, which introduced the first beach planning measures, and in 1970 the first guidelines with specific regulations for the urban beaches management were published (Ariza, 2007). These guidelines were subsequently embodied in a new Coastal law (Law 22/88 of Coasts 1988) and Regulation 1471/ 89. This law significantly changed approach to and practice of beach management, establishing new competences for the different Spanish administrations.

Theoretically, responsibilities in coastal management are distributed across three levels of the state administration (Ariza et al., 2008; Coastal law 2/2013): i) the Central Administration, that manages the coastal public domain; ii) the Regional Administration, that manages land-use planning; and iii) the Local Administration, which is responsible for the maintenance and provision of services to users. This distribution of competencies gives rise to great confusion during the decision-making process that is necessary to achieve the proper solutions for the manager (Palazón et al., 2016). Thus, one of the problems is the management of certain uses (which may be private, although in no case represents a change of land ownership) within the maritime-terrestrial public domain (MTPD) (Coastal law 22/1988). The occupation of the MTPD can generate conflicts between the licensee and the beach users, which requires precise management of this sensitive area. Thus, these high activity concentration areas are classified as special interest (Amoedo-Souto, 2009; Torres, 2009).

One of the tasks that beach managers must perform is to pay special attention to the evolution of the shoreline, since there are studies that demonstrate its continuous retreat because of coastal erosion. This regressive process relentlessly generates a smaller beach surface area (Alexandrakis et al., 2015; Pagán et al., 2016, 2017, 2018). EC (2004) states that traditional local management models are not a good way to solve erosion problems, since the spatial scale of many of these problems goes beyond the local level, yet these managers are in charge of their maintenance and operation. Therefore, from the tourism industry point of view, an appropriate ecosystem management must take into account the relationships between society and ecosystems (Jiménez et al., 2007).

According to the present Spanish Coastal Law, any occupation of the state MTPD public property assets with permanent works or facilities, or removable facilities for a period greater than four years, will be subject to a prior concession agreement granted by the State Administration in public bidding. In this case, concession contracts imply for the designed operator to have the exclusive right to operate, maintain and carry out a user-paid service on public property (e.g., a beach) for a given number of years, in exchange for an annual concession fee. These occupations may not be granted for a period exceeding five years, extendable for equal periods of time.

This work analyses the shoreline evolution of 31 beaches (all of them with a strong tourism presence) in 5 Spanish provinces, and their relationship with the management. At the same time, specifications of concessions (surface area, set boundaries, distances from the concession area to the coastline, annual fee) are studied. Finally, it evaluates whether the concession contract specifications are complied with by the concessionaires (concession areas and distances to the coastline), and the existence of a possible relationship between the concession areas and the evolution of the coastline between the 2005-2016 period.

\section{Study area}

The study area comprises 31 beaches on the Mediterranean coast, located in the provinces of Valencia (5), Alicante (7), Murcia (4), Almeria (8) and Granada (7), whose coasts have very different physical characteristics (Fig. 1). The area to the north of Cape Nao (Alicante) borders with marshlands intensely transformed by agricultural activity, whereas to the south up to the city of Alicante, the coast is characterized by a landscape of coves and cliffs. Further south, there are extensive beaches and coastal lagoons such as Torrevieja or Guardamar, with some islets off the coast.

On the Murcia coast, the effect of wind on the sand gives rise to an important dune field that has closed the coastal lagoon of the Mar Menor (higher temperature and salinity than the outer sea). The southern part of the province is made up of cliffs with small beaches. In this area and the province of Alicante there are important seabed areas where Posidonia oceanica meadows stand out.

In the provinces of Granada and Almeria, the foothills of the Betic Mountains near the coast determine very narrow coastal plains, except for the valleys of some rivers. The rivers are short, with markedly seasonal regimes, some with ephemeral currents, but with a significant sediment discharge during the floods.

The tides in the Mediterranean are not constant in time and vary in terms of the type of tide (diurnal, semidiurnal and mixed). They usually have astronomical amplitudes between 0.2 and $0.4 \mathrm{~m}$, so they are considered micro-tides but near the strait area, the amplitude of the tides increases to $0.72 \mathrm{~m}$ (Ecolevante, 2006; Ecomag, 2009).

The studied beaches (Table 1) have high occupation (over 90\%) and urbanization (over $80 \%$ ) levels, with sand beaches $(70.9 \%$ ) predominating over gravel beaches (25.8\%). In the southern beaches (provinces of Granada and Almería), dark sands predominate, compared to the other provinces with mostly golden sands (Magrama, 2016).

\section{Methodology}

According to Codignotto (1987), for the purpose of this article, "beach" shall mean the area of unconsolidated material extending towards land from the low tide line to where there is a noticeable change in material or in physiographic conditions, or where the vegetation line is permanent. Maritime-terrestrial public domain (MTPD) is defined in Article 3 of the Coastal Law 1988. MTPD comprises the following zones: sea shore and estuaries, including intertidal zones, beaches, coastal dune fields and similar deposits; marshes, lagoons and generally lowlands flooded by tidal flows; territorial and inland waters, including their bedding and subsoil; and natural resources within the economic zone and the continental platform.

To determine the erosion and retreat of the beach shoreline, as well as to determine the concession area used and its position on the beach, orthophotos were used between 2005 and 2016 (most recent available) obtained from PNOA (Plan Nacional de Ortofotografía Aérea) website (http://pnoa.ign.es/ortofotos). In order to digitalize the different surfaces, ArcGis software (software specialized in Geographic Information Systems) was used. For the shoreline digitalization, the criterion followed was the choice of the last wet tide mark on the sand (Casal et al., 2010).

Starting from the polygons generated by the ArcGis software for each of the studied beaches, and taking into account the beach nourishments carried out (information provided by the Directorate General of Coasts), the following data were obtained: i) Total beach surface area; ii) Concession area or area included within the concession perimeter; and iii) Net beach area or difference from the other two. 

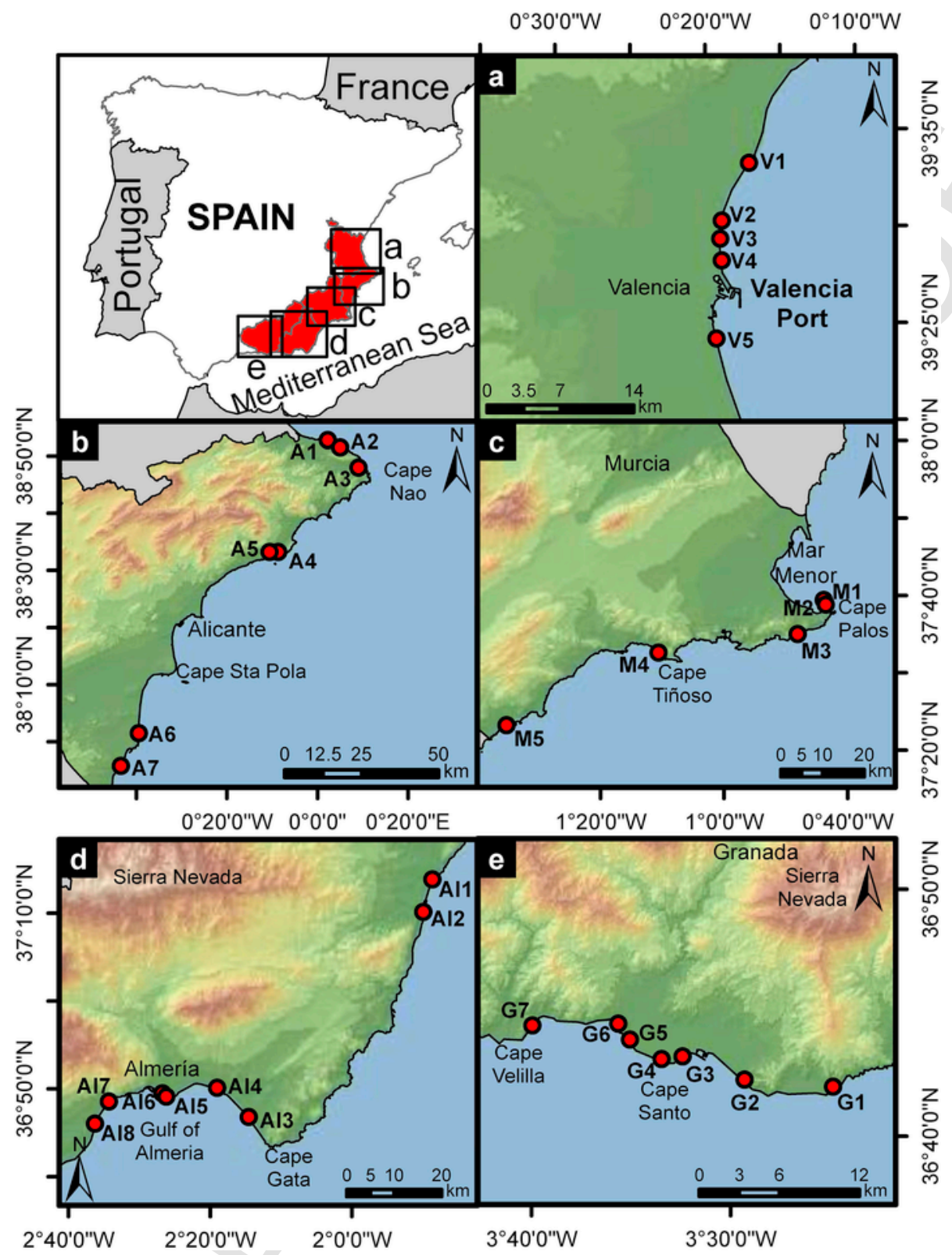

Fig. 1. Location of the study area and the analysed beaches. a) Valencia province. b) Alicante province. c) Murcia province. d) Almería province. e) Granada province.

The data about the physical characteristics of the beaches (sediment typology and length) were obtained from the online beach guide edited by the Ministerio de Agricultura, Pesca, Alimentación y Medio Ambiente (Magrama, 2016).

Finally, the specifications for the administrative concessions were obtained from the web pages of the city councils, where the bids for seasonal services are published. In Table 1, those beaches where administrative documents could not be found nor provided by the respective councils are filled with the "N/A" (data not available) text.

\section{Results and discussion}

Beaches represent an important attraction for a host of establishments (bars, restaurants, umbrella and hammock rentals, beach bars, water sports rentals, etc.) that, in most cases, require authorization to operate their businesses as a concession, due to the location of these within the MTPD (article 115 Coastal Law 22/1988). As a result, there is an important concentration of activities in the beach environment, giving rise to large concentrations of users and significant socio-economic repercussions. For this reason, these areas are classified as special interest and relevance to the Spanish coastline (Amoedo-Souto, 2009).

The extent of the shoreline retreat has varied within the study area, ranging from large to small retreats (Table 1; the surface areas obtained in each of the studied years can be seen in supplementary material 1). This process is also evident in almost every beach on the Spanish coast (Aragonés et al., 2015; Chiva et al., 2018; Jiménez et al., 1997). Beaches such as Marineta Cassiana $\left(8762.6 \mathrm{~m}^{2}\right.$; $\left.-42.0 \%\right)$ or Granada $\left(-34,130.2 \mathrm{~m}^{2} ;-45.9 \%\right)$ have suffered large surface area losses (Table 1 ), while other beaches have gained surface area, but taking into account the sand nourishments made, the final balance is negative. This is the case of Marchamalo, Calahonda or Zapillo (Table 1). Beach morphology, sediment type, wave energy, tides, etc., are factors that have played a role in the degree of the shoreline retreat (Aragonés et al., 2015, 2016; Marcomini and López, 1997; Pagán et al., 2016). 
Table 1

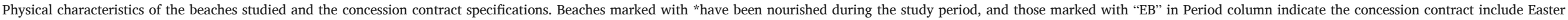
Break. "N/A" indicates data not available in concession documents.

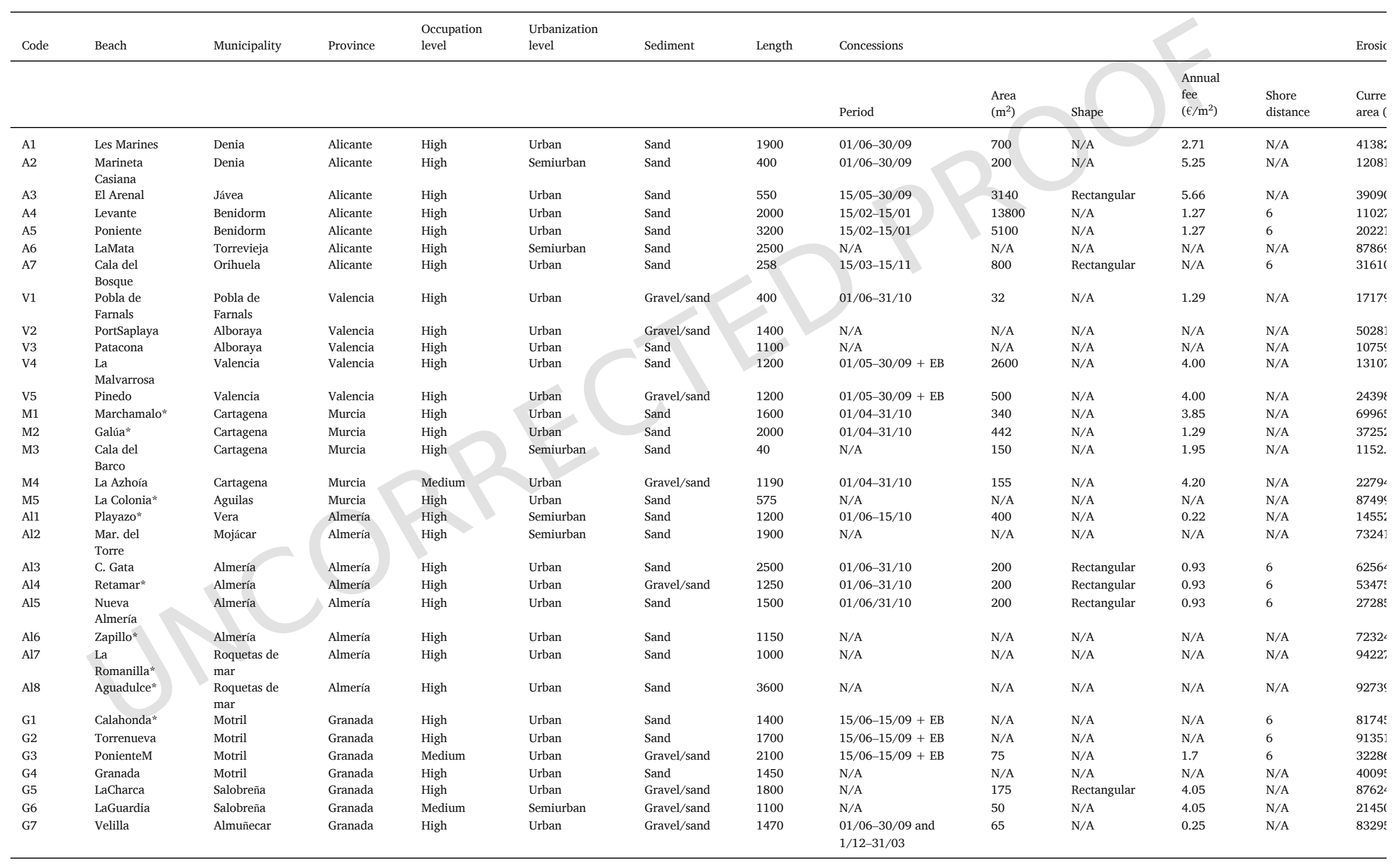


Beach occupation, including season services, could not exceed half of its surface at high tide according to Spanish coastal law. Therefore, the concession contracts established for the occupation of part of the beach (MTPD) by hammock and umbrella rental firms must be in accordance with the beach surface area specifications. Otherwise, it can cause a loss of useful beach surface area (to the beach user) and an increase in people density, possibly to over populating the beach (Fig. 2). However, as shown in Fig. 3a, there is no correlation between concession area and beach area. Perhaps one of the problems is the lack of consensus in research on beach facilities or required safety (Scherer et

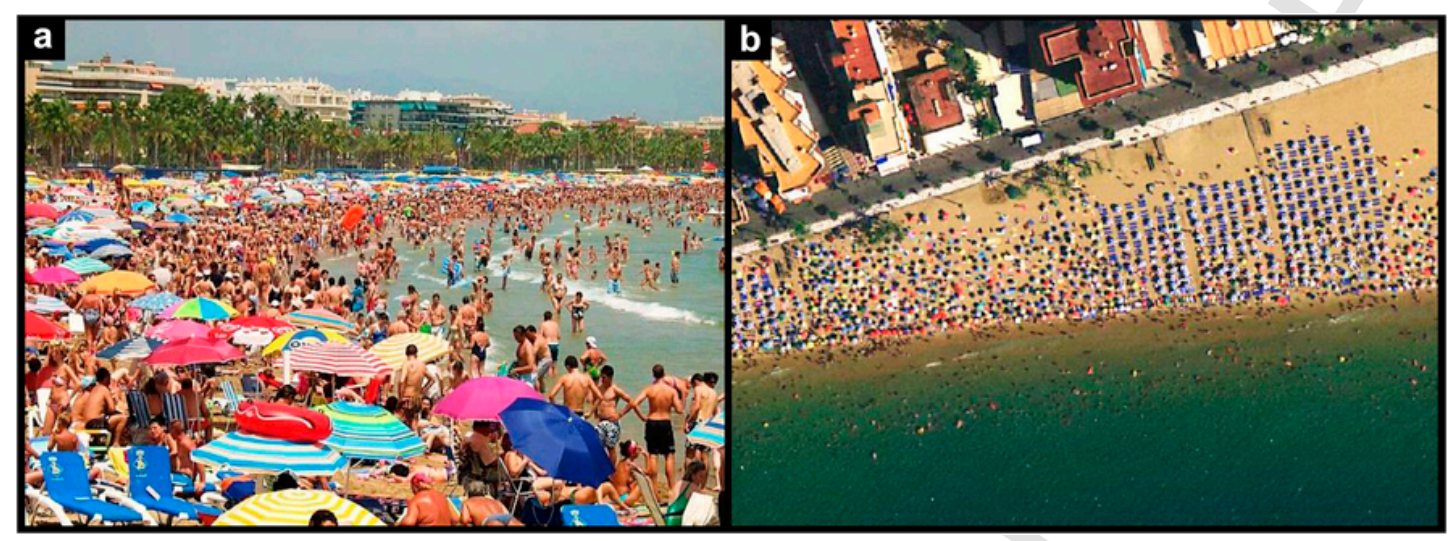

Fig. 2. Saturated Levante Beach (Benidorm).

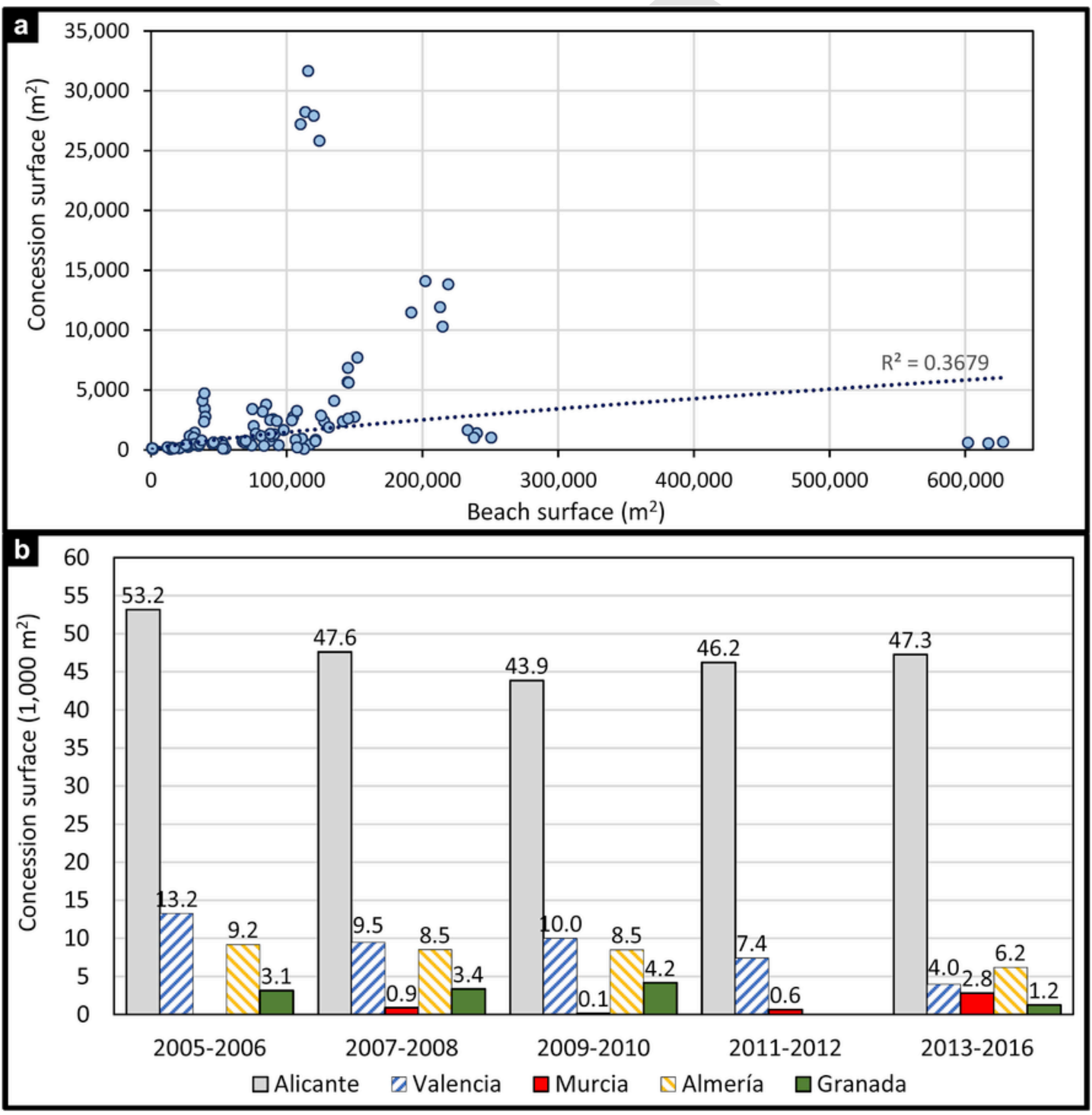

Fig. 3. a) Correlation between the area of beaches and the area of concessions. b) Evolution of the concession area by province. 
al., 2014). From the analysis of the evolution of concession surface area (measured) by province (Fig. 3b), it can be seen that both Alicante and Murcia show a variation marked by the downturn in the 2009-2010 period (economic crisis), after which the concession area increases again, but in Valencia, Almeria and Granada the concession area tends to decrease. It should also be noted that concession areas are only a small proportion of the beach surface area (Table 1). In Alicante, the area occupied by the concession is less than $6 \%$ of the beach, while in the other provinces it does not exceed $2 \%$, although there are always exceptions such as the Levante beach in Benidorm (24.7\%) or the Cala del Barco $(10.8 \%)$. The lack of correlation (Fig. 3a) is directly related to the lack of administrative convergence, because despite the Provincial Head Offices of Coasts (belonging to the General Directorate of Coasts) authorizing the concession specifications, each the concession contract is different, depending on the Beach involved.

Furthermore, the concessionaire does not comply with the surface area, position or geometric shape set out in the concession contract (Fig. 4). It can be clearly seen that the concessionaire's objective is: i) occupy as much space as possible in order to place as many units (umbrellas and/or hammocks) as possible and maximise profit. Increases in the real occupied surface area can be generally observed (Table 2), ranging from $1.9 \%$ in the Poniente (Benidorm, Alicante) or $3.7 \%$ of the Pobla de Farnals (Valencia) to $86.5 \%$ in Galúa (Murcia) or el 104.3\% en Marchamalo (Murcia). Although there are also decreases that can reach $82.2 \%$ of Patacona or $75.7 \%$ of the Malvarrosa (both in Valencia). ii) Improve comfort for customers, as seen in Levante beach where the concessionaire is located around the beach accesses (Fig. 4a). This situation is detrimental to the other beach users by altering the beach carrying capacity (Jiménez et al., 2007), which has negative effects due to the current mode of coastal management (Sánchez, 2001).

From the analysis of the specifications, only the Benidorm concession contract refers to a possible decrease in the area originally awarded due to the shoreline retreat (Supplementary material 2). The other administrative documents analysed do not refer to this problem, although it is pointed out that the Spanish Administration could reduce the concession area without explicitly mentioning the shoreline retreat. Not taking into account the variation of the beach surface area when determining the concession surface area may cause changes in carrying capacity. Therefore, for beaches whose most important economic activity is tourism (as in the case of Benidorm), carrying capacity (despite being a dynamic value) should be a basic indicator of integrated coastal zone management (Botero and Diaz, 2009; Jiménez et al., 2007; Valdemoro García, 2005).

The distance between the concession and the shoreline was also analysed, noting that not all concessions regulate it and in those that are regulated the distance is $6 \mathrm{~m}$, complying with this distance in most cases (Fig. 4). However, no mention was found in the coastal legislation or regulations relating to this distance. Although, as the tidal range in the analysed area is less than $0.72 \mathrm{~m}$ (Puertos del Estado; www.puertos.es), this parameter does not have a significant influence in terms of reducing the $6 \mathrm{~m}$ walking area for beach users.

Another aspect to consider is the distance between the beach users and the shoreline. The study shows that in most of the beaches, users are located less than $40 \mathrm{~m}$ from the shoreline (Fig. 5). This is consistent with da Silva's (2002) and Jurado (2015) studies, where most beach users are located less than $50 \mathrm{~m}$ from the sea. This could be related to the sand temperature and the distance from the swimmer to the water.

The study of the annual fees of the concession areas $\left(€ / \mathrm{m}^{2}\right)$ obtained from the different concession contracts, shows that there is a significant variation in prices between the different concessions (Table 1). However, these differences are not related, as might be thought, to existing demand. Thus, it is observed that mainly tourist beaches, such as Benidorm or La Malvarrosa (Valencia) have very different values, $1.27 € / \mathrm{m}^{2}$ compared to $4 € / \mathrm{m}^{2}$, respectively. When analysing the aver-

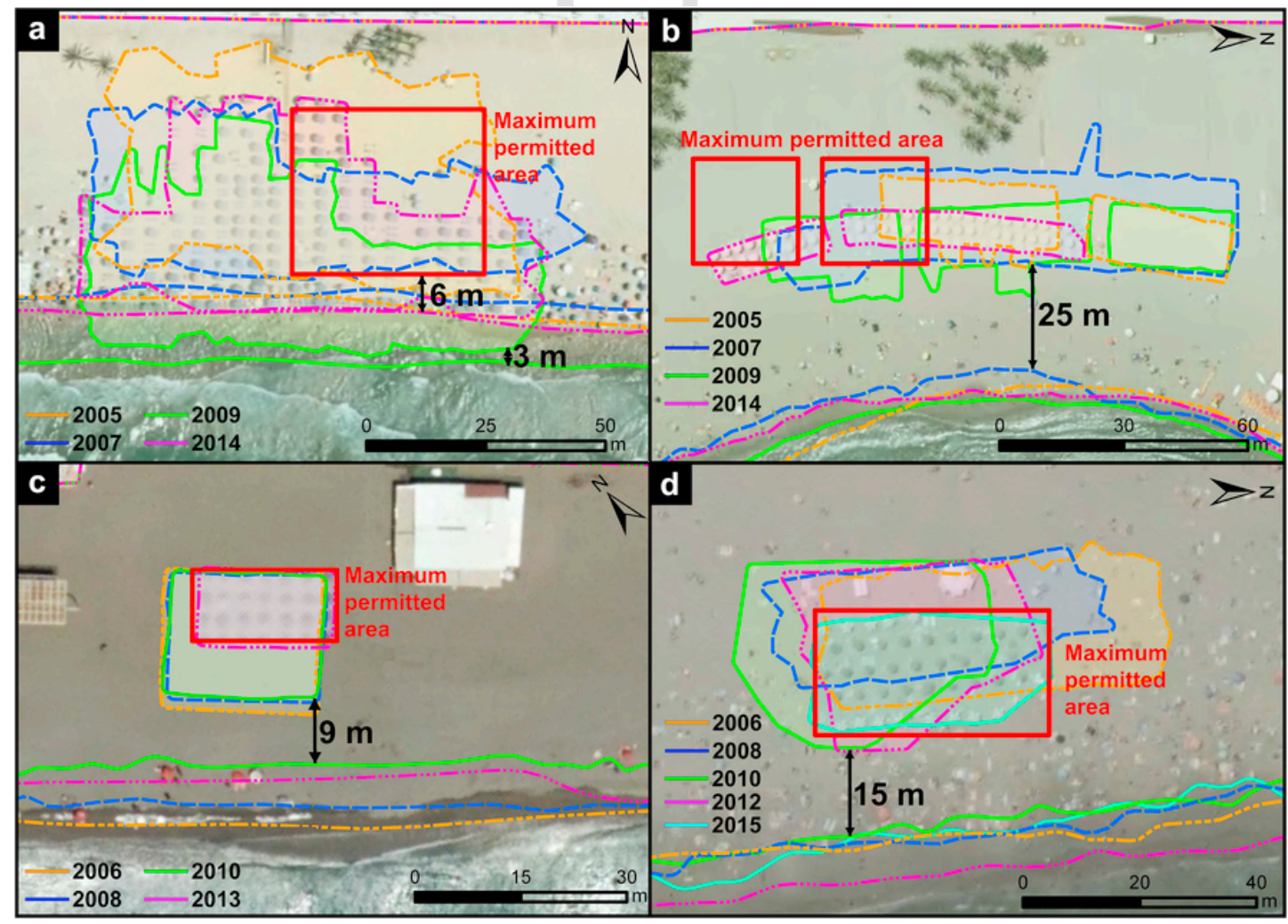

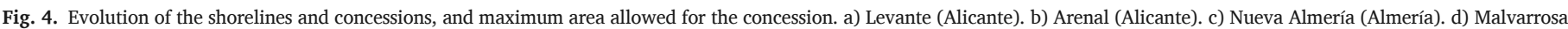
(Valencia). 
Table 2

Relationship between official concession data and those measured on each beach.

\begin{tabular}{|c|c|c|c|c|c|c|c|c|c|c|}
\hline \multirow[t]{2}{*}{ Beach } & \multirow[t]{2}{*}{ Municipality } & \multirow[t]{2}{*}{ Province } & \multirow[t]{2}{*}{ Period } & \multicolumn{3}{|c|}{ Measured concession area $\left(\mathrm{m}^{2}\right)$} & \multicolumn{2}{|c|}{ Official concession } & \multicolumn{2}{|c|}{ Average difference } \\
\hline & & & & Initial & Final & Variation & Data & Surface area $\left(\mathrm{m}^{2}\right)$ & $\mathrm{m}^{2}$ & $\%$ \\
\hline Les Marines & Denia & Alicante & & & & & YES & 700.0 & & \\
\hline Levante & Benidorm & Alicante & $2005 / 2014$ & 31639.8 & 27203.3 & $-14.0 \%$ & YES & 13800.0 & 15621.6 & $113.2 \%$ \\
\hline Poniente & Benidorm & Alicante & $2005 / 2014$ & 13808.4 & 14068.6 & $1.9 \%$ & YES & 5100.0 & 8838.5 & $173.3 \%$ \\
\hline El Arenal & Jávea & Alicante & $2005 / 2014$ & 3421.5 & 2338.6 & $-31.6 \%$ & YES & 3140.0 & -260.0 & $-8.3 \%$ \\
\hline Marineta Casiana & Denia & Alicante & $2005 / 2014$ & 115.8 & 196.7 & $69.8 \%$ & YES & 200.0 & -43.8 & $-21.9 \%$ \\
\hline La Mata & Torrevieja & Alicante & $2005 / 2014$ & 2742.5 & 2468.5 & $-10.0 \%$ & NO & & & \\
\hline Cala del Bosque & Orihuela & Alicante & $2005 / 2014$ & 1424.8 & 999.7 & $-29.8 \%$ & YES & 800.0 & 412.3 & $51.5 \%$ \\
\hline Pinedo & Valencia & Valencia & $2006 / 2012$ & 1369.7 & 999.6 & $-27.0 \%$ & YES & 260.0 & & 924.61 \\
\hline Pobla de Farnals & Pobla de Farnals & Valencia & $2006 / 2015$ & 105.8 & 109.7 & $3.7 \%$ & YES & 110.0 & -2.3 & $-2.1 \%$ \\
\hline Patacona & Alboraya & Valencia & $2006 / 2012$ & 4082.8 & 727.0 & $-82.2 \%$ & NO & 1125.0 & & 1279.91 \\
\hline Port Saplaya & Alboraya & Valencia & & 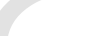 & & & NO & 1069.0 & & \\
\hline La Malvarrosa & Valencia & Valencia & $2006 / 2015$ & 7685.3 & 1866.3 & $-75.7 \%$ & YES & 1400.0 & 3375.8 & $155.9 \%$ \\
\hline Marchamalo & Cartagena & Murcia & $2007 / 2016$ & 360.9 & 737.4 & $104.3 \%$ & YES & 737.0 & -187.9 & $-25.5 \%$ \\
\hline Cala del Barco & Cartagena & Murcia & $2007 / 2016$ & 88.0 & 124.1 & $41.1 \%$ & YES & 124.0 & -17.9 & $-14.5 \%$ \\
\hline Galúa & Cartagena & Murcia & $2007 / 2016$ & 418.0 & 779.6 & $86.5 \%$ & YES & 780.0 & -181.2 & $-23.2 \%$ \\
\hline La Azhoía & Cartagena & Murcia & & & & & YES & 155.0 & & \\
\hline Zapillo & Almería & Almería & & & & & NO & & & \\
\hline Nueva Almería & Almería & Almería & $2006 / 2013$ & 442.2 & 211.3 & $-52.2 \%$ & YES & 211.0 & 115.8 & $54.9 \%$ \\
\hline C. Gata & Almería & Almería & $2005 / 2010$ & 646.9 & 578.2 & $-10.6 \%$ & YES & 200.0 & & 412.53 \\
\hline Mar. del Torre & Mojácar & Almería & $2006 / 2013$ & 1986.4 & 581.3 & $-70.7 \%$ & NO & 581.0 & 702.9 & $121.0 \%$ \\
\hline Retamar & Almería & Almería & $2005 / 2010$ & 490.8 & 503.9 & $2.7 \%$ & YES & 200.0 & & 297.31 \\
\hline La Romanilla & Roquetas de Mar & Almería & & & & & NO & & & \\
\hline Aguadulce & Roquetas de Mar & Almería & $2006 / 2013$ & 3753.6 & 2392.7 & $-36.3 \%$ & NO & 2393.0 & 680.2 & $28.4 \%$ \\
\hline Playazo & Vera & Almería & $2006 / 2013$ & 2364.0 & 2618.1 & $10.7 \%$ & YES & 2618.0 & -126.9 & $-4.8 \%$ \\
\hline Granada & Motril & Granada & $2005 / 2010$ & 352.3 & 644.2 & $82.9 \%$ & NO & & & \\
\hline Velilla & Almuñecar & Granada & $2006 / 2013$ & 1112.0 & 323.7 & $-70.9 \%$ & YES & 324.0 & 393.9 & $121.6 \%$ \\
\hline Calahonda & Motril & Granada & & & & & NO & & & \\
\hline Poniente & Motril & Granada & & & & & YES & 75.0 & & \\
\hline Torrenueva & Motril & Granada & $2005 / 2010$ & 432.4 & 194.8 & $-54.9 \%$ & NO & & & \\
\hline La Guardia & Salobreña & Granada & $2006 / 2013$ & 321.0 & 149.6 & $-53.4 \%$ & YES & 150.0 & 85.3 & $56.8 \%$ \\
\hline La Charca & Salobreña & Granada & $2006 / 2013$ & 929.3 & 756.6 & $-18.6 \%$ & YES & 175.0 & 86.0 & $11.4 \%$ \\
\hline
\end{tabular}




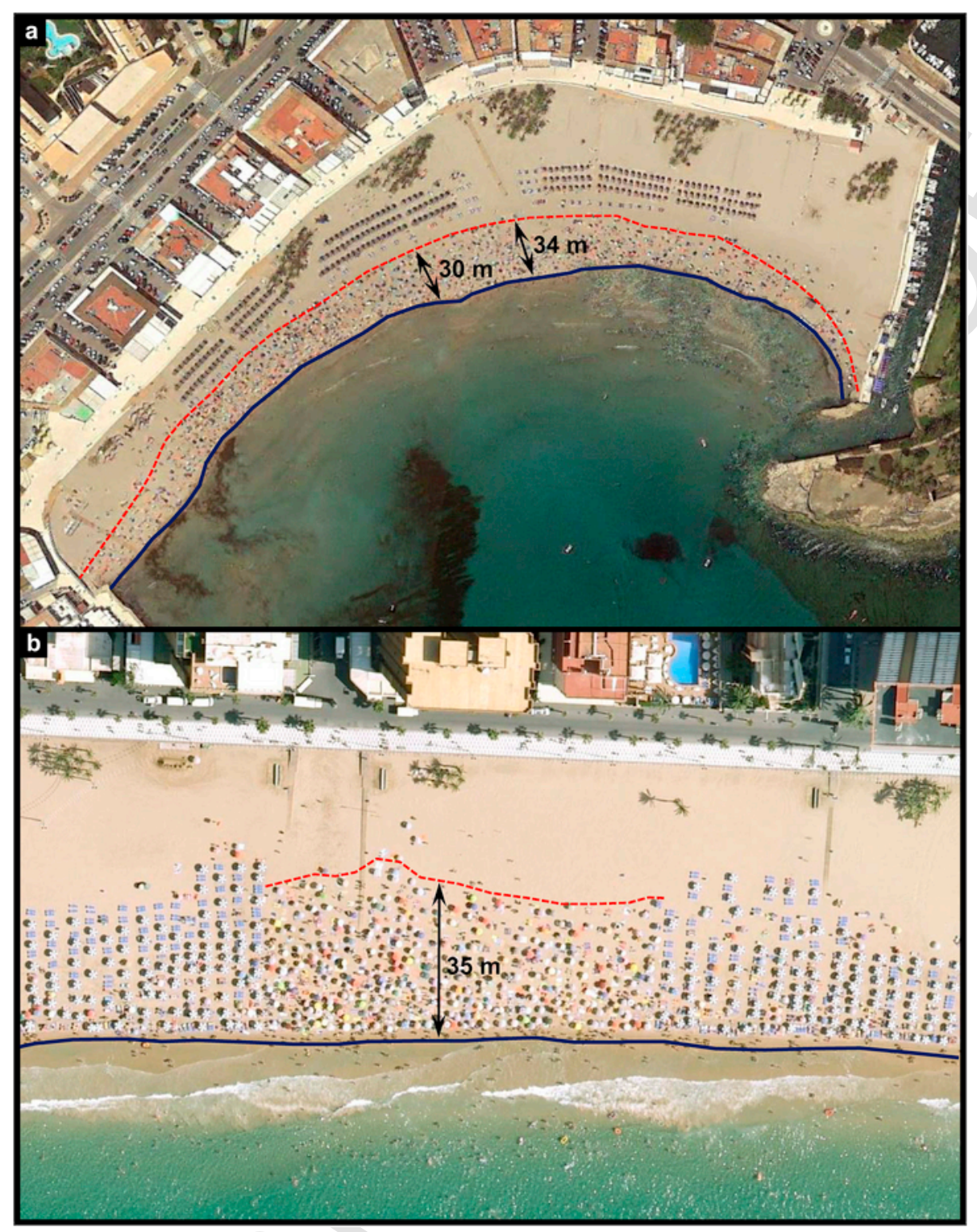

Fig. 5. Location of beach users from the shoreline. a) Arenal (Alicante). b) Levante (Alicante).

age annual fees per concession by provinces, Almería is the cheapest with an average of $0.84 € / \mathrm{m}^{2}$ and Alicante and Murcia the most expensive with around $3 € / \mathrm{m}^{2}$. Concerning the concession period, all concessions generally run from June to October, including the Easter period on some beaches. However, Benidorm is an exception, with a concession period of 11 months.

Therefore, even though some researchers argue that the beach is an ecosystem at risk and unable to absorb a greater anthropogenic impact (Aragonés et al., 2015; Pagán et al., 2017), others underline the importance of tourism development for the economy of a territory because it is a reference sector worldwide (Craig, 2016; Sardá et al., 2014). For Spain, tourism is a highly important social and economic activity; therefore, reconciling the functionality of these spaces with the problems associated with the conservation and stability of the seaside is a key priority. This is especially important for Spain's Mediterranean beaches, as they are frequented on a massive scale. The management of the MTPD should be compatible with the evolution of the coastline in a way that maintains ecosystem management criteria and does not contribute to beach degradation or saturation. The concession contract specifications should also clearly indicate the area, geometry, distance from the coastline, and additionally the retreat of the coastline as a decisive factor in reducing the concession area.

\section{Conclusion}

The study carried out shows that the concession areas have no relation to the beach surface area or to the evolution of the coastline. In addition, concessionaires generally do not comply with either the area or the set boundaries detailed in the concession contract specifications, although the minimum distance to the shoreline $(6 \mathrm{~m})$ is met. All this can damage the satisfaction of users by reducing the zone of free movement in the beach area, which can lead tourists to choose other destinations.

The lack of uniformity in the criteria specified for the different concession contracts is partly due to legislative loopholes in coastal management. Although it is the Spanish Directorate-General for Coasts that must authorise the specifications, they should be initiated at local level by using common criteria nationwide (surface area, set boundaries, distance to the coast, etc.). However, the overlapping and uncoordinated 
jurisdictions between national and local administrations makes it difficult for this to happen.

The information and communication technologies era provides the possibility of creating tools that give both the beach manager and the beach user information that leads to a more efficient management of resources and enables the coexistence of both elements (tourism and the beach). The issue is not to ban attractive leisure activities on the coast but to make sure that they are carried out in a manner that is sustainable and environmentally friendly.

\section{Acknowledgment}

The authors thank the Ministerio de Agricultura, Alimentación y Medio Ambiente and Organismo Público Puertos del Estado, for the information they provided has enabled this study. As well as to all members of the councils for having attended and answer our questions.

This research did not receive any specific grant from funding agencies in the public, commercial, or not-for-profit sectors.

\section{Appendix A. Supplementary data}

Supplementary data related to this article can be found at https:// doi.org/10.1016/j.ocecoaman.2018.05.011.

\section{References}

Aguiló, E., Alegre, J., Juaneda, C., 2003. La viabilidad de los destinos turísticos de masas. El caso de las Islas Baleares. In: Proceedings of the XII Simposio de Turismo y Ocio ESADE (Barcelona (Spain)). p. 20.

Alexandrakis, G., Manasakis, C., Kampanis, N.A., 2015. Valuating the effects of beach erosion to tourism revenue. A management perspective. Ocean Coast. Manag. 111, 1-11.

Amoedo-Souto, C.A., 2009. El patrimonio cultural litoral: apuntes para la integración del patrimonio cultural en la gestión del litoral. Patrim. Cult. derecho 13, 55-86.

Aragonés, L., García-Barba, J., García-Bleda, E., López, I., Serra, J.C., 2015. Beach nourishment impact on Posidonia oceanica: case study of Poniente beach (Benidorm, Spain). Ocean. Eng. 107, 1-12.

Aragonés, L., Pagán, J.I., López, M.P., García-Barba, J., 2016. The impacts of Segura River (Spain) channelization on the coastal seabed. Sci. Total Environ. 543, 493-504.

Ariza, E., 2007. A System of Integral Quality Indicators as a Tool for beach Management. Master's thesis Universitat Politècnica de Catalunya, Barcelona, Spain, 186p.

Ariza, E., Jiménez, J.A., Sardá, R., 2008. A critical assessment of beach management on the Catalan coast. Ocean Coast. Manag. 51 (2), 141-160.

Bainbridge, J., Potts, T., O'higgins, T., 2011. Rapid policy network mapping: a new method for understanding governance structures for implementation of marine environmental policy. PLoS One 6 (10), e26149.

Barragán, J., 2005. La gestión de áreas litorales en España y Latinoamerica. Publicaciones Universidad de Cadiz, Cádiz (Spain), 198.

Botero, C., Diaz, L., 2009. La playa como espacio costero particular en la Gestión Integrada Costera, revisión desde la bibliografía especializada. Rev. Medio Ambiente, Sustentabilidad Tur. 2, 99-107.

Breton, F., Clapés, J., Marquès, A., Priestley, G.K., 1996. The recreational use of beaches and consequences for the development of new trends in management: the case of the beaches of the Metropolitan Region of Barcelona (Catalonia, Spain). Ocean Coast. Manag. 32 (3), 153-180.

Casal, G., Sánchez-Carnero, N., Freire, J., 2010. Generación de una línea de costa digital de Galicia (NW España) a gran escala, utilizando fotointerpretación y segmentación dinámica. Bol. Asoc. Geógr. Españoles (53), 7-19.

Codignotto, J.O., 1987. Glosario Geomorfológico Marino. Asociación Geológica Argentina, Texas, USA, 70.

Cormier, R., Kannen, A., Davies, I., Sardá, R., Diedrich, A., 2010. Policy fragmentation implications in ecosystem-based management in practice. In: Proceedings of the Proceedings of the ICES Annual Science Conference (Nantes, France). pp. 20-24.
Craig, J.F., 2016. Freshwater Fisheries Ecology. John Wiley \& Sons, Hoboken, USA, 899

Chiva, L., Pagán, J.I., López, I., Tenza-Abril, A.J., Aragonés, L., Sánchez, I., 2018. The effects of sediment used in beach nourishment: study case El Portet de Moraira beach Sci. Total Environ. 628-629, 64-73.

Da Silva, C., 2002. Beach carrying capacity assessment: how important is it?. J. Coast. Res. (SI36), 190-197.

Dormios, R., Dolle, C., Rocher, A., Schneider, M., 2000. Fréquentation touristique des plages. Étude des clientèles. Agence Françoise de l'Ingénierie Touristique.

EC European commission, 2004. Part I-Major Findings and Policy Recommendations of the EUROSION Project. Living with Coastal Erosion in Europe: Sediment and Space for Sustainability. Official Publications of the European Communities, Luxembourg, 57.

Ecolevante, 2006. Estudio ecocartográfico del litoral de las provincias de Alicante y Valencia. Dirección General de Costas, Ministerio de Medio Ambiente, Spain, Available online: http://www.mapama.gob.es/es/costas/temas/proteccion-costa/ecocartografias/ ecocartografia-alicante.aspx.

Ecomag, 2009. Estudio ecocartográfico de las provincias de Granada, Almería y Murcia. Dirección General de Costas, Ministerio de Medio Ambiente, Spain, Available online: http://www.mapama.gob.es/es/costas/temas/proteccion-costa/ecocartografias/ ecocartografia-murcia.aspx.

EEA Eropean Environmental Agency, 2006. The Changing Faces of Europe's Coastal Areas. Report No 6/2006 Eropean Environmental Agency, Copenhagen, 112

Holden, A., 2000. Environment and Tourism. Routledge, Taoylor and Frnacis Group, London, 278.

Jiménez, J.A., Osorio, A., Marino-Tapia, I., Davidson, M., Medina, R., Kroon, A., Archetti, R., Ciavola, P., Aarnikhof, S.G.J., 2007. Beach recreation planning using video-derived coastal state indicators. Coast. Eng. 54 (6), 507-521.

Jiménez, J.A., Sánchez-Arcilla, A., Bou, J., Ortiz, M.A., 1997. Ocean \& coastal management. J. Coast. Res. 13, 1256-1266.

Jurado, J., 2015. Análisis de dinámicas de elementos de ocupación en playas urbanas de Tarragona. In: De La Riva, J., Ibarra, P., Montorio, R., Rodrigues, M. (Eds.), Análisis Espacial Y Representación Geográfica: Innovación Y Aplicación. Universidad de Zaragoza-AGE, Zaragoza, Spain, pp. 661-670.

Keul, A., 2015. The fantasy of access: neoliberal ordering of a public beach. Polit. Geogr. 48, 49-59.

Magrama, 2016. Guía de playas [Online]. Ministerio de Agricultura, Alimentación y Medio Ambiente. Gobierno de España, Available: www.mapama.gob.es/es/costas/servicios/ guia-playas/2016.

Marcomini, S.C., López, R.A., 1997. Influencia de la urbanización en la dinámica costera, Villa Gesell, provincia de Buenos Aires, República Argentina. Rev. Asoc. Argent. Sedimentol. 4 (2), 79-96.

Pagán, J.I., Aragonés, L., Tenza-Abril, A.J., Pallarés, P., 2016. The influence of anthropic actions on the evolution of an urban beach: case study of Marineta Cassiana beach, Spain. Sci. Total Environ. 559, 242-255.

Pagán, J.I., López, I., Aragonés, L., Garcia-Barba, J., 2017. The effects of the anthropic actions on the sandy beaches of Guardamar del Segura, Spain. Sci. Total Environ. 601-602, 1364-1377.

Pagán, J.I., López, M., López, I., Tenza-Abril, A.J., Aragonés, L., 2018. Study of the evolution of gravel beaches nourished with sand. Sci. Total Environ. 626, 87-95.

Palazón, A., Aragonés, L., López, I., 2016. Evaluation of coastal management: study case in the province of Alicante, Spain. Sci. Total Environ. 572, 1184-1194.

Sánchez, E., 2001. Informe sobre la Gestión Integrada de las Zonas Costeras en España. El auge del turismo europeo en la España de los años sesenta. Arbor. CLXX 669, 201-224.

Sardá, R., Ariza, E., Jimenez, J.A., 2012. Buscando el uso sostenible de las playas, Palma de Mallorca (Spain). Societat d'història natural de les Balears.

Sardá, R., Avila, C., Mora, J., 2005. A methodological approach to be used in integrated coastal zone management processes: the case of the Catalan Coast (Catalonia, Spain). Estuar. Coast. Shelf Sci. 62 (3), 427-439.

Sardá, R., Pintó, J., Valls, J.F., 2014. Hacia un nuevo modelo integral de gestión de playas. Documenta Universitaria, Girona (Spain), 2032.

Scherer, M., Costa, M.F., Boski, T., Azeiteiroe, U.M., Dias, J.A., 2014. Integrated coastal management in Latin America: the ever new world. Revista de Gestão Costeira Integrada-J. Integr. Coast. Zone Manag. 14 (4), 663-668.

Torres, F.J., 2009. La ocupación del dominio público marítimo terrestre en España. Investig. Geográficas 50, 63-91.

UNWTO, 2018. 2017 International Tourism Results: the Highest in Seven Years [Online] World Tourism Organization, United Nations http://media.unwto.org/press-release/ 2018-01-15/2017-international-tourism-results-highest-seven-yearsAccessed 11 May 2018.

Valdemoro García, H., 2005. La influencia de la morfodinámica en los usos y recursos costeros. Universitat Politècnica de Catalunya, Barcelona, Spain, Master's thesis. 